\title{
Academic youth as a representative of a new phase in a social development. On the condition of identity in early adulthood
}

\section{KEYWORDS}

emerging adulthood, identity styles, postmodernity

\begin{abstract}
Ławiak Alicja, Academic youth as a representative of a new phase in a social development. About the condition of identity in youthfulness. Culture - Society - Education no 2(16) 2019, Poznań 2019, pp. 235-244, Adam Mickiewicz University Press. ISSN 2300-0422. DOI 10.14746/ kse.2019.16.15.
\end{abstract}

The post-modern reality, including the multitude of changes and expanding volumes of offers force the individual to continually redefine themselves. A person existing in contemporary reality is permanently on the search for their identity, in order to finally find the most suitable one, which (as it usually turns out nowadays) does not exist. Youths make a choice within the range of education offers. They more often than not decide to study, with studying being the reason for delaying the moment of entry into adulthood and taking over social roles that are specific for the period of young adulthood. In making this choice, young people enter the phase of so-called emerging adulthood, which for a while now has been a new, separate phase of development, fitting in between adolescence and young adulthood. They are not passing through the complex process of puberty any more, however, they do not always have a mature identity. They find themselves in a period characterised by intense exploration. The article attempts to describe the specifics of this stage, additionally presenting an overview of studies on the mode of coping with issues of identification characterising the early adulthood period. 


\section{Introduction}

Literature frequently presents a kind of structure that brings human life in order in three phases. This theory is found for instance in the work by Anna Brzezińska, which, following Erik Erikson, recalls the stages of childhood, youth and adulthood (Brzezińska, 2003: 1-3). However, can this common subdivision be still considered current? The group of students seems problematic in this regard. Considering the age to be the determining factor, on the one hand, we ascribe to this group, without wondering too much, the guise of being adults. However, considering the fact that the stage of adulthood is also related to certain specific properties, more precisely, tasks assigned to this phase of development (according to Piotr Oleś, these are: starting a family, undertaking professional activity, taking responsibility for oneself and for others as well as autonomy with respect to the decisions being made and with respect to one's emotional development - Oleś, 2011:17-19), then the group at hand can largely not be assigned to the phase that is adulthood yet. This is because it does not fulfil these requirements. As it additionally turns out, in post-modern times in which we are living, we are dealing with the phenomenon of delaying entry into adulthood. The period of studying sometimes extends even up to the age of 35 (Wysocka, 2013: 69-96). Researchers thus have started to discern a further stage of development, placing it in between adolescence and adulthood, and naming it ,emerging adulthood". What are the properties of this newly distinguished phase and what are the identity issues that contemporary young individuals must face? - these and other questions shall be answered by the present article.

\section{A phase between adolescence and adulthood}

In psychology, one usually encounters the theory dividing human life into three phases. In to this concept, A. Brzezińska describes, following E. Erikson, the phases of childhood, youth and adulthood. Accordingly, in a more detailed subdivision, the researcher indicates the periods forming the constituent components of the stages named above:

I. Infancy, post-infancy, preschool and school stage $=($ CHILDHOOD $)$

II. Growing up $=($ YOUTH $)$;

III. Early adulthood, middle adulthood, late adulthood = (ADULTHOOD).

The psychologist associates childhood with the stage of life determined as the age between zero and 12 years, describing adolescence as the period between the 10th/ 12th and 18th/20th year of age, with adulthood described as making up the 
period between 18/20 years of age and death (Brzezińska, 2003: 1-3). Were one to follow this train of thought, one should also include academic youth, being aged 19-26 years, in the stage of adulthood. Does this, however, fit in with the reality and the specifics of human activity in the post-modernity that we are witnessing?

Ewa Wysocka presents a slightly different structure of human life, suggesting four main stages, meaning: childhood, youth, adulthood and old age. The end of the period of adolescence (youth), according to the author, equals the achievement of a precise (mature) identity, independence, the feeling of full responsibility (not only for oneself, but for others as well), and the release of all forms of egocentrism (Wysocka, 2010: 49-53). P. Oleś indicates similar criteria of entry into adulthood, speaking of the execution of significant tasks in life (including starting a family, undertaking professional activity), taking responsibility for oneself and for others as well as autonomy in decisions and in one's own emotional development (Oleś, 2011: 17-19). Adult is hence seen as a form of maturity. According to Maria Czerepaniak-Walczak (Czerepaniak-Walczak, 2007: 1), in turn, the predictor for the achieved maturity is the solution to certain tensions that remain in opposition towards each other and are characteristic for adolescence. These are the following dilemmas:

- enthusiastic participation in common existence vs the need for solitude;

- submission to authority vs opposition against patterns;

- pro-societal attitude vs egoism and egocentrism;

- engagement vs passivity;

- optimism and dreaming vs pessimism and lack of sense;

- entrancement in light of tasks one has set for themselves vs the feeing of hopelessness;

- ecstasy vs numbness. ${ }^{1}$

As part of the criteria for adulthood, one must mention the factors that are presently considered to be the most objective in diagnosing this stage of development. Psychologists dealing with the issue of entering adulthood discern between such indicators as: moving out of the family home and running one's own, concluding the process of education, entering into a marriage (establishing a permanent intimate relationship), having children and undertaking a fixed employment related to working full time (Brzezińska, Piotrkowski, Kaczan, Rękosiewicz, 2011: 71).

\footnotetext{
${ }^{1}$ As M. Czerepaniak-Walczak writes, it is worth noting that more and more young people fuse learning with gainful work, which, together with the lack of solution to these tensions, leading to a characteristic overload, may interfere in the process of gaining maturity. Studies by M. Czerepaniak-Walczak show that $24 \%$ of youths that learn (aged 19-25) learn while being employed.
} 
In light of the studies of Anna Brzezińska, Radosław Kaczan, Konrad Piotrowski and Małgorzata Rękosiewicz one can eagerly state that even though academic youth fits in the age group indicating early adulthood (the concept of E. Erikson), however, taking into account the specifics of contemporary times, they have not entered this stage yet. The main reason for the delay in entering adulthood is the process of education that is doubtless continuously extending. As a consequence, an entirely new phase of development arises that was given the name of „emerging adulthood” (Brzezińska, Piotrkowski, Kaczan, Rękosiewicz, 2011: 70) or „rising adulthood” (Wysocka, 2013: 69-96). This period is defined as a time beginning at the age of ca. 18 years, lasting most frequently until the age of 25/26 (Brzezińska, Piotrkowski, Kaczan, Rękosiewicz, 2011: 71-71) (according to certain sources, sometimes slightly longer, occasionally even up to the age of 35 Wysocka, 2013: 69-96), between adolescence and adulthood. „Leaving behind the dependence characteristic for childhood and, and not taking on permanent adult social roles and the related responsibilities, people in this transitional stage devote time to exploring the possible directions of human activity, exploring intensely, most commonly in the area of intimate relationships, work and ideology" (Brzezińska, Piotrkowski, Kaczan, Rękosiewicz, 2011: 70-71).

\section{Identity at the threshold of adulthood}

The delay of one's entry into adulthood not only applies to an extension of the process of education but also delays related to the process of crystallisation of identity. Not only does academic youth not take up the social roles that are typical for adulthood, ${ }^{2}$ but it largely does not feel adult at all (Rękosiewicz, 2016: 314).

The process of formation of identity (according to the concept of James Marcia) takes place in two stages - exploration and responsibility, which until the present were included among characteristics of adolescence. Exploration entails mainly discovering oneself among diverse activities, and responsibility - reaching decisions on actions that are significant for the individual. Hence, one finds themselves following a testing phase - to which they submit themselves. In the most desirable case, acquiring a reply to the question „Who am I?", they enter adulthood

2 As H. Liberska (2003) shows in her paper, the tasks of early adulthood (found by the researcher to be in the period of 23-34 years of age) include: choosing a life partner and learning to live together with them, taking on family roles related to having offspring, bringing this offspring up, keeping a household, undertaking a professional career and doing one's civic duties as well as finding a social group. 
(Brzezińska, Appelt, Ziółkowska, 2016: 266). This conclusion inspires an analysis, in particular in light of studies and statements by Anna Brzezińska, Radosław Kaczan, Konrad Piotrowski and Małgorzata Rękosiewicz. As it turns out, exploration (assigned in earlier studies to the age between 11/12 and 14/ 15 years) falls in the period of emerging adulthood. What is significant, in employed people, a lower factor for it was found than among students. At the same time, it was noticed that in individuals that have not taken up studies that the feeling of adulthood is significantly higher, and the direction of their aspirations - better defined (Brzezińska, Piotrkowski, Kaczan, Rękosiewicz, 2011: 75).

Ewa Wysocka undertakes in her paper an attempt to characterise the subject found in the new development phase, being a specific one for post-modernity. She presents fundamental properties, among which one can find: lack of an established feeling of identity, the need for experimentation in the professional field, with geographic space and numerous identities related to the categories of real, perfect, expected. In addition, the researcher indicates such properties of youths as: exhibiting risky behaviour, the need for psychological and institutional support, attempting a preliminary balance of one's experience through the supranational, cross-border and intercultural perspective as well as empirical openness with respect to the categories of life, culture and the everyday reality (Wysocka, 2013: 79). The research explorations of E. Wysocka show that academic youth perceives itself mostly as adults. However, the understanding of the concept of "adulthood" reminds of the view presented by adolescents, who bind the concept of „adulthood” with „freedom and decision independence” (Wysocka, 2013: 83). It is a status characteristic for early adulthood, which primarily equals undertaking specific roles, and which is found relatively rarely in statements by students (Wysocka, 2013: 79). Without a doubt, in a time of liquid modernity, the individual experiences the need to constantly redefine themselves, through which permanent exploration is achieved (Krauze-Sikorska, 2013). The stage of emerging adulthood becomes the culmination in this respect, because as Anna Brzezińska, Radosław Kaczan, Konrad Piotrowski and Małgorzata Rękosiewicz write, it in this stage that young people „devote time to explore possible directions of life activity and explore intensely, primarily in the areas of intimate relationships, work and ideology" (Brzezińska, Piotrkowski, Kaczan, Rękosiewicz, 2011: 71), hence, such areas of life that are an inseparable part of adult existence, at the same time forming the foundation of human survival (Wysocka, 2013: 78).

Of key importance for the aspect of identity of academic youths at the threshold of adulthood is research on the styles of identity of this age group, which, according to Michael Berzonsky hint at specific modes of coping with problems of 
identification (Cybal-Michalska, 2014: 242). They show significant differences in the modes of collecting information on oneself by the individual and the way they transform it, creating a vision of themselves or defending themselves against the same becoming established (Malinowska, Sobczak, 2016: 229). Among the three styles (informational, normative as well as diffuse-avoidant), one seems to emerge the most commonly in students. Studies by Agnieszka Cybal-Michalska show that the informational stile is most common here. „People with the informational identity style act in a calculated manner, intentionally searching, assessing and referring to information that is useful to them (...) characterising individuals that ponder their own views, reevaluating them frequently." (Cybal-Michalska, 2014: 242). This is doubtless related to self-reflection, openness to new experiences, subjective activity, the feeling of agency and coping with problems with the use of resources that are rationalism and conscientiousness. This style is additionally related to the status of identity moratorium ${ }^{3}$ characterised by the need to discover reality and described by engagement in extremely diverse activities in order for the individual to in the end find its own path, and itself along it. A further, slightly less frequent style of coping with the identity maelstrom is the normative style, related to an assigned identity status, further bound to the rejection by the individual of information that could oppose its individual views and values they adhere to. This style may include unease and the feeling of guilt. The style least common among academic youths is the diffuse-avoidant style related to the attitude of delaying decisions and solving conflicts of identification. It can be associated with the status of diffuse identity that is found in most cases towards the very beginning of the difficult process of establishment of identity, and which brings itself a sort of "chaos” in terms of identity. It must be stressed at this point that among the analysed youths, A. Cybal-Michalska diagnoses a factor representing engagement, being a force that implies within an individual the feeling of direction and the ability to control their behaviour through the filter of the feedback it receives (Cybal-Michalska, 2014: 238-247). „Stabilised personal engagement, playing a significant role in the description of the power and clarity of moral standards, convictions and purposes of activity, supports the achievement of well-being by an individual" (Senejko, 2007: 105). The above explorations are proof that academic youths are characterised by the status of achieved identity.

What is interesting is that, comparing self-knowledge of students and upper secondary school level pupils, slight differences are found. This conclusion is re-

\footnotetext{
${ }^{3}$ In the identity status concept of J. Marcia, the following are discerned: diffusion, foreclosure, moratorium and identity achievement.
} 
flected in studies by Klaudia Malinowska and Weronika Sobczak (Malinowska, Sobczak, 2016: 227-246), which show that the informational stile (just like among academic youths) is found in school-age youths most frequently, with the next most frequent being the normative style, followed by the diffuse-avoidant style. ${ }^{4}$ An important piece of information is here the fact that the studied population are pupils of vocational school complexes. One is drawn by the conclusion that the type of school attended by a youth is also significant. Pupils attending technical, vocational schools or profiled general schools, just like students, are close to undertaking full-time gainful employment (from which the last stage of education separates them). This would doubtless require a more thorough analysis that could aid in finding a higher number of correlations, however, this notion seemed clear and establishing a certain logical whole in light of studies by A. Cybal-Michalska, K. Malinowska and W. Sobczak. Meanwhile, studying the work of E. Gurba, this hypothesis could be considered erroneous.

Looking at the styles of identity of pupils of lower and upper secondary schools, one notices the same tendency. Studies by Ewa Gurba (Gurba, 2010: 79-92) show that youths in these types of schools, similarly to academic youth or youths attending vocational school complexes, also most frequently represent the informational style, less frequently the normative style, and the diffuse-avoidant style least frequently. What is significant is that differences between lower and upper secondary school pupils seem minor. Solely the factor of engagement is statistically significantly different, as upper secondary school pupils represent a higher factor than lower secondary school pupils. ${ }^{5}$

If we already know the identity styles of youths - both pupils as well as students, one should take a closer look at styles represented by young adults. Uncommonly interesting is the fact how much the styles of adolescents differ from the styles of young adults. Studies by Dorota Czyżowska, Ewa Gurba and Arkadiusz Białek (Czyżowska, Gurba, Białek, 2012: 57-68) show in line with supposi-

${ }^{4}$ Studies were conducted in technical schools, profiled upper secondary schools or such schools with profiled classes and basic vocational high schools in Poznań. The result for the informational style was 4.18 ; for the normative style -3.04 , and the diffuse-avoidant style -2.32 (the maximum achievable score was 5 ).

${ }^{5}$ The study by E. Gurba included 145 lower secondary school and 324 upper secondary school pupils, with the mean age being 16.26. The studies used the Identity Style Inventory by M. Berzonsky adapted by A. Senejko. The studied individual was to respond to 40 statements on a five-point Likert scale. The informational identity scale was found on average in 33.9 lower and 35.2 upper secondary school pupils, the normative scale in 29.08 lower and 30.26 upper secondary school pupils, and the diffuse-avoidant scale was observed in 26.8 lower and 26 upper secondary school pupils. The scale of engagement was represented on average by 33.4 lower and 34.7 upper secondary school pupils. 
tions that the most frequently emerging mode of coping with problems of identity among young adults is naturally the informational style, with the normative style and the diffuse-avoidant style being least common. The mean of prevalence of the informational style is $\approx 37$, of the normative style $\approx 30$ and of the diffuse-avoidant style $\approx 25 .{ }^{6}$ The results differ slightly from those for school pupils.

One can hence notice that both adolescents, emerging persons as well as those already in adulthood represent different styles of coping with identity issues. Would one focus on academic youths, being the subject of analysis of the present article, one must not forget the factor of engagement stressed in the studies (Cybal-Michalska, 2014: 239-240). It turns out to be the most characteristic for the styles of identity represented by students. It is worth noting that identity engagement is related to the feeling of meaning, the direction of one's existence and the value system; it facilitates supervision of one's behaviour and their control. It is reflected in one's proactive attitude towards the emerging issues of identification. „Without a doubt, the style of identity of academic youths that refers to the factor of engagement had shown its transition from the internal exploration phase to the phase of undertaking responsibility, which, as A. Brzezińska indicates, is an exemplification of a completely achieved identity." (Cybal-Michalska, 2014: 242).

\section{Summary}

As a scientific issue, emerging adulthood is a certain novelty in terms of cognitive theory for development psychology as well as for education scientists who attempt to describe its specifics. This stage shines through as a separate phase in the entire human life. This means that it does not contain particularities characteristic not only for the period of late adolescence or characterising only early adulthood. It was formerly thought that the acquisition of a very stable identity is a sign of entry into adulthood. It turns out today that identity may be transformed at any point in life. Hence, the status of a fully formed identity does not seem to be a sign of adulthood, but in turn - undertaking developmental tasks that are specific for this stage (unique for the undertaking that is the establishment of a family) (Brzezińska, Piotrowski, 2009: 93-109). As a consequence of existing in postmodernity, young people frequently delay entry into adulthood until the completion of studies and

${ }^{6}$ D. Czyżowska, E. Gurba and A. Białek studied 637 persons aged 22-40, with the mean age being 29.09 . 
finding full-time employment. They may not take up family roles even until the 35th year of age (Wysocka, 2013: 69-96). Without a doubt, the new phase of development that is emerging adulthood is a consequence of the permanent changes and the breadth of possibilities that give rise in an individual to continuously redefine themselves. As Weronika Syska writes, it seems necessary in contemporary times to equip youths with certain universal abilities that will help them adapt to new, emerging circumstances. Education scientists, psychologists as well as parents should establish among the future adults the competences that are essential for living: analytical thinking, being able to draw conclusions, emotional intelligence, intercultural mentality, information processing, digital competences, design thinking, work in an information-permeated environment and cooperation in the virtual world. It is doubtless that the institution that is the school should be the source of these competences and skills, as it prepares the people participating in the globalising reality to enter adult life (Syska, 2016: 327-343).

\section{Bibliography}

Brzezińska A. (2003), Portrety psychologiczne człowieka. Jak zmienia się człowiek w ciągu życia? Remedium vol. 122, no 4, pp. 1-3.

Brzezińska A., Appelt K., Ziółkowska B. (2016), Psychologia rozwoju człowieka, Sopot.

Brzezińska A., Piotrowski K. (2009), Diagnoza statusów tożsamości w okresie adolescencji, wyłaniającej się dorosłości i dorosłości za pomocą Skali Wymiarów Rozwoju Tożsamości (DIDS), Przeglad Psychologiczny no 47, pp. 93-109.

Brzezińska A., Piotrowski K., Kaczan R., Rękosiewicz M. (2011), Odroczona dorosłość: fakt czy artefakt? Nauka no. 4, pp. 67-107.

Cybal-Michalska A. (2014), Młodzież akademicka a kariera zawodowa, Kraków.

Czerepaniak-Walczak M. (2007), Stereotypy młodzieży - konieczność i możliwość odczarowania młodości, [in:] M. Dudzikowa, M. Czerepaniak-Walczak (eds.), Wychowanie. Pojęcia - procesy konteksty. Interdyscyplinarne ujęcie, Gdańsk, vol. 1.

Czyżowska D., Gurba E., Białek A. (2012), Typ orientacji społecznej a sposób konstruowania własnej tożsamości przez młodych dorosłych, Psychologia Rozwojowa 17 no. 3, pp. 57-68.

Gurba E. (2010), Związek między stylami tożsamości i jakością relacji z rodzicami u młodzieży gimnazjalnej i licealnej, Psychologia Rozwojowa 15, no. 4, pp. 79-92.

Krauze-Sikorska H. (2013), Tworzenie tożsamości społecznej i przynależności grupowej w Internecie, [in:] H. Krauze-Sikorska, M. Klichowski, Świat Digital Natives. Młodzież w poszukiwaniu siebie i innych, Poznań.

Liberska H. (2003), Realizacja zadań rozwojowych dorosłości a rozwój indywidualny, [in:] B. Harwas-Napierała (ed.), Rodzina a rozwój człowieka dorosłego, Poznań.

Malinowska K., Sobczak W. (2016), Statusy tożsamości a style tożsamości u progu dorosłości, [in:] A. Brzezińska, W. Syska (eds.), Ścieżki wkraczania w dorosłość, Poznań.

Oleś P. (2011), Psychologia człowieka dorosłego, Warszawa. 
Rękosiewicz M. (2016), Typy partycypacji społecznej na przełomie dorastania i dorosłości, [in:] A. Brzezińska, W. Syska (eds.), Ścieżki wkraczania $w$ dorosłość, Poznań.

Senejko S. (2007), Style kształtowania tożsamości u młodzieży a ustosunkowanie wobec zagrożeń, [in:] B. Harwas-Napierała, H. Liberska (eds.), Tożsamość a współczesność, Poznań.

Syska W. (2016), Diagnoza i pomoc psychologiczna dla młodzieży. Rekomendacje na podstawie wyników badań, [in:] A. Brzezińska, W. Syska (eds.), Ścieżki wkraczania w dorosłość, Poznań.

Wysocka E. (2010), Doświadczanie życia w młodości - problemy, kryzysy i strategie ich rozwiązywania, Katowice.

Wysocka E. (2013), Wschodząca dorosłość a tożsamość młodego pokolenia - współczesne zagrożenia dla kształtowania tożsamości. Analiza teoretyczna i empiryczne egzemplifikacje, Colloquium Wydziału Nauk Humanistycznych i Społecznych, Kwartalnik I, pp. 69-96. 